whether the fuel is coal or coke; the proportion of sulphur in coke is roughly the same as in the coal from which it is made.

Pollution by grit from the burning of coal and coke in domestic appliances is not easily prevented, though fortunately it is not very great.

Substitution of gas for solid fuel would avoid pollution by smoke and grit and would reduce pollution by sulphurous gases to a negligible amount. The use of electricity in place of solid fuel avoids the production of smoke, but would not prevent pollution by grit and sulphurous gases unless the generating stations are equipped to remove the grit and sulphur from the chimney gases. In general, however, gas and electricity are too expensive for continuous heating in the average house, but they have advantages in many circumstances for short-period intermittent heating and for cooking.

So far as domestic appliances are concerned it would seem that encouragement should be given to the use of coke, gas, and electricity in place of coal, so far as is economically practicable, if atmospheric pollution is to be greatly reduced. But the changes suggested could only take place gradually, if the demands for the various fuels and forms of energy are not to overstep the supply; and there must be a suitable balance if the resources of the different types of coal are to be used to the best advantage in the broad national interest. It should be pointed out that all the possibilities have not been covered : for example, the possibilities of communal central heating and district heating have not been discussed. It is hoped, however, that this broad review will serve to indicate the general lines along which progress can be made.

\section{COAL MINING IN GREAT BRITAIN}

$I^{\mathrm{T}}$ $\mathrm{T}$ would be difficult to exaggerate the importance of the Report of the Technical Advisory Committee on Coal Mining, presumably to be known as the Reid Report*. For almost a century, coal mining in Great Britain and its special aspects have been the subject of inquiry for royal commissions and departmental committees, and in the past few months much has been written on the reorganization of the industry. However, the Reid Report is without parallel. Seven distinguished mining engineers have examined the present lamentable position, and have set out in detail their proposals for the creation of a prosperous and efficient industry. Mr. Reid and his colleagues have expressed their views with complete frankness, and have criticized impartially mine-owner, mining engineer and workman. If ever the term 'blue-print' could be applied to a document, then this report is a blue-print for the post-war mining industry in Britain.

The approach to the problem is historical, and Part 1 includes a revealing comparison of the coal industry of Britain with those of the principal Continental nations. If two nations are mining coal under approximately similar natural conditions, then the output of coal per man-shift worked can be regarded as a measure of the efficiency of mining. Similarly, records of output per man-shift over several years will provide evidence of improvement or de-

* Ministry of Fuel and Power. Coal Mining : Report of the Technical Advisory Committee. (Cmd. 6610.) Pp. ix +150 . (London : H.M. Stationery Office, 1945.) 18. net. terioration in the mining situation of a particular nation. In any comparison of statistics of output per man-shift careful account must be taken of the natural conditions under which the coal is worked. In the United States, mining conditions are greatly superior to those prevailing in Britain, and in Poland mining is carried on under the best natural conditions in Europe. However, in Holland and on the Ruhr, conditions are certainly no better than those of the British coalfields. Although useful conelusions can be drawn from the statistics of American mining, for a fair comparison we must turn to our Continental neighbours, and particularly to Holland and the Ruhr.

Those who desire an account of the vicissitudes of the British coal trade/must refer to the report itself. The most significant period is that between the years 1927 and 1939 , and it is sufficient here to say that, in spite of the introduction of several thousand mechanical coalcutters during the years 1913-27, output per man-shift showed little improvement from the 20.32 cwt. of 1913 to the 20.62 ewt. of 1927. Some progress was made in the years 1927-36, when the output increased by some 14 per cent to $23 \cdot 54$ cwt., a maximum for the period between the Wars. Small as the increase appears, it was achieved only as a result of intensive mechanization - the tonnage of coal mechanically cut increased from $58 \cdot 5$ to $142 \cdot 2$ million tons between 1927 and 1939, while the tonnage carried on face conveyors increased from 28 millions in 1928 to 134 millions in 1939. Taking Great Britain as a whole, the situation in the coal mines left little room for complacency.

In 1914 Britain was able to dominate the seaborne coal trade of the world, and substantially retained this position until 1925, when Poland and Germany first assumed the position of serious competitors. To compare British and Continental progress the Committee has adopted as the basic year that in which each country attained the 1913 level of output per man-shift, and the following table is extracted from the report.

\begin{tabular}{lcccc}
\multicolumn{1}{c}{ Country } & $\begin{array}{c}\text { Basic } \\
\text { year }\end{array}$ & $\begin{array}{c}\text { Output per man-shift } \\
\text { in basic year } \\
\text { cwt. }\end{array}$ & $\begin{array}{c}\text { in 1936 } \\
\text { cwt. }\end{array}$ & $\begin{array}{c}\text { Percentage } \\
\text { increase }\end{array}$ \\
Poland & 1927 & $23 \cdot 44$ & $36 \cdot 20$ & \\
Holland & 1925 & $16 \cdot 48$ & $35 \cdot 94$ & 118 \\
The Ruhr & 1925 & $18 \cdot 62$ & $33 \cdot 66$ & 81 \\
Britain & 1927 & $20 \cdot 62$ & $23 \cdot 54$ & 14
\end{tabular}

Comparison with the United States would be unjustified, but it should be noted that the output per man-shift in the American bituminous mines amounted to 93.8 cwt. in 1939 .

Many reasons are advanced for this failure to attain, or even approach, Continental standards of output. The British industry has long lacked the financial resources to undertake major long-term improvements, and considering the low average profit per ton-7d. during the years $1929-38$ - this is not surprising. Conditions of mineral ownership have proved a disastrous handicap to the mines of Britain. Until 1942 the minerals were privately owned, and there remains a legacy of small and awkwardly shaped leaseholds, worked by an excessive number of mines, many of which are of low capacity. On the Continent the amalgamation of undertakings has resulted in the concentration of production in large well-equipped mines. In 1938 the Ruhr mines were of an average capacity of 778,000 tons per year; 
the twelve mines of Holland averaged 1,200,000 tons per annum. Britain, too, has mines of large capacity, but there are many small mines. In 1943, 90 per cent of the output came from 816 mines owned by 353 separate undertakings. The average yearly output per mine was 228,000 tons.

Relevant as are the above and other important conclusions, the recommendations on the details of practical mining form the backbone of the report. The hidden complexities of underground mining make the discussion of this section no easy task, and it is proposed to emphasize two fundamental operations - those of getting and transporting the coal. In Britain, most of the coal seams are worked by the 'longwall advancing system' of mining-some 74 per cent of the collieries are so laid out. Less popular, but giving good results under certain conditions, are the 'room and pillar' and 'longwall retreating' systems.

The room and pillar system was an early development in British mining practice. Here the seam is first divided into pillars of side $20-50 \mathrm{yd}$., by driving two sets of roads at right-angles. Developed a century ago in the coalfields of Northumberland and Durham, the method gives best results in shallow seams of $a$ suitable thickness, say, 5-6 ft. When, however, attempts were made to work the deeper seams by room and pillar, many difficulties were encountered. Because of the great pressure on the pillars, there was an excessive 'crush' on the workings, the pillars tended to disintegrate, and the roads to close in. Pillar extraction, a normal and safe operation at shallow depth, was made difficult and often impossible. The system also proved unsuited to the working of thin seams, and there was thus a gradual change over to the 'longwall' system of working. However, the room and pillar system is almost universal in the United States-with the important difference that the workings are highly mechanized. Since 1941, American methods of production have been studied by British engineers, and it is considered that a proportion of the British output could, in future, be won from mechanized room and pillar workings. Experimental lay-outs have been equipped on American lines, and the results are sufficiently encouraging to suggest that the system will find a useful, if limited, application in Britain. The outstanding feature of American methods is that a very high proportion of the workers is engaged on actual coal production, and this accounts in some measure for the high output per man-shift.

Natural conditions in Britain have proved most suited to the 'longwall advancing' system. In its modern application a straight wall of coal or 'face', say, 200 yd. long, is prepared. Two mechanical conveyors are laid along the face, each feeding on to a main conveyor in the centre and at right-angles to the face. The coal worked is filled on to the conveyors, and loaded on to 'tubs' (small wagons) at a loading point at the end of the main conveyor. An average rate of advance is $5 \mathrm{ft}$. per day-that is, a block of coal $200 \mathrm{yd}$. long, of height equal to the thickness of the seam, and $5 \mathrm{ft}$. in depth is removed. The whole of the equipment and supports must thus be advanced $5 \mathrm{ft}$. per day. More important, the empty space, or goaf, left behind the advancing face, must be partially packed with debris, and roads must be prepared and maintained through the goaf. This is unproductive work, inherent in this system of mining, and absorbs the labour of substantial numbers of underground workmen. Nevertheless, the method has many technical advantages, anc will long find an important place in British minin practice.

The 'longwall retreating' system combines, ir some measure, the advantages of the other twc systems. Roads, known as headings, are driven ir. the seam to a pre-determined boundary to form a pillar, say, $300 \mathrm{yd}$. long and $100 \mathrm{yd}$. wide. This pillar is then extracted back towards the main road from which the headings were started. So far, the system has not been widely used in Britain, but there are reasons to believe that, with the use of modern machinery for intensive development, longwall retreating could well be applied in many British mines, with a consequent reduction in the proportion of unproductive labour.

The Committee thus recommends a complete reconsideration of established mining methods. Mechanized room and pillar should be applied where conditions are sufficiently favourable. Since this will by no means be generally applicable, consideration should be given to the use of longwall retreating methods, and finally the longwall advancing system should be applied to those circumstances in which the other two systems are unsuitable.

In the nineteenth century, practically the whole output of British mines was won by means of the hand pick. Now some 80 per cent of the coal is undercut by mechanical coalcutters. After undercutting, holes are bored in the coal, and these charged with explosive and fired, so leaving the coal in a suitable condition for hand filling by means of a shovel. In 1939 , on every working day, nearly $1,000,000$ tons of coal came from the shovels of the British miners. If the operation of loading could be mechanized, there are clearly possibilities of a tremendous saving in labour. For room and pillar work there are excellent machines of British and American manufacture, used for lifting the broken coal from the floor to a conveyor or tub. Loading machines of a diferent type are required for longwall faces, and the design of a suitable machine is a difficult technical problem. Nevertheless, British manufacturers have produced loading machines of distinct promise, and these are in use in experimental installations. That the Committee attaches the greatest importance to their further application is clear from the statement "that development in mining technique must be directed, first and foremost, to a reduction in, and ultimately to the practical elimination of hand loading".

A mechanical loader, however efficient, has one important limitation-a coalcutter must first be used to prepare the coal for loading, and the use of explosives may also be necessary. The Committee envisages the use of machinery which will be capable of simultaneously cutting and loading the coal. At least one machine of this type has been used, and the prototypes of other machines are nearing completion.

Traditional haulage practice provokes the keenest criticism. In British mines there is apparently a serious wastage of labour in hauling the coal from the working face to the shaft bottom. One haulage worker is required for every 50 tons of coal produced in the United States, for every 20-25 tons in Holland, and for every 5 tons in Britain. There is evidently much to be learned from a study of American and Continental haulage methods.

Wire-rope haulage is standard practice in British coal mines. Conveyors may be used to bring the coal to a loading station, and from there the tubs 
re hauled to the shaft by means of wire ropes driven $y$ stationary engines. In an old or badly laid-out ine, the coal may be hauled by a succession of such ngines, each haulage requiring its complement of ttendants. Conveyors could be much more widely sed to transport the coal to well laid-out loading tations, so eliminating the wasteful use of labour n subsidiary haulage systems.

In the United States and on the Continent, locoaotives are widely used underground. But the use $f$ locomotives requires roads which are level, or early so, and the present lay-out of most British aines is such as to prohibit their widespread installaion. Roads have been driven in the coal seams, and in general the gradients are unsuited to the use if locomotives. Continental seams are more inclined, und the practice there is to drive level roads through he solid strata, these serving as the main arteries if the mine along which the locomotives operate. Reorganization for locomotive haulage will require he preparation of great lengths of graded roadways, ind if the full advantages of locomotive haulage are io be realized, mine cars of a high capacity will be equired. The capacities of the tubs used in British nines range from 3 to $28 \mathrm{cwt}$. - the average is probibly 12 cwt. For use with locomotives, mine cars will be required each capable of holding several tons of coal.

No details of mining practice are passed over in this unique survey. Standards of mine lighting, the Committee considers, could be materially improved with advantage to production, safety and health. Illumination at the coal face is now provided by portable self-contained lamps, but it is recommended that power-fed lighting should be installed at the coal face. Recent research has shown that the 'cold' cathode discharge lamp may, well prove a safe and efficient means of illuminating underground workings.

In an interesting paragraph the appearance of colliery premises is discussed. It is true that in the past little or no attention has been paid to this point, and the "disorder and dilapidation" so often associated with colliery premises must have its psychological effects on the workmen and adversely influence public opinion on the state of the industry. An architect should be consulted when plans are being prepared for a new mine or for remodelling an old mine.

It is apparent that reform on the lines suggested in the Reid Report will require major changes in the organization of the coal-mining industry in Britain, and this is discussed under "Conditions of Success". There will need to be amalgamation of many of the smaller undertakings to form productive units of a much greater capacity, and many existing mines will become redundant. There is a note of warning to the workmen and their leaders: that if existing wage-levels are to be maintained, then there must be a considerable increase in output per manshift, and that a rebuilt industry may have to dispense with substantial numbers of unskilled workers.

In the past, the layman may have formed the view that Britain's coal problem was that of utilizing her abundant resources of coal. This report puts first things first the fundamental problem is that of min. ing the coal efficiently, and any plans for the utilization of coal depend primarily on the availability of large quantities of cheap coal. Finally, those with no special knowledge will read the report without difficulty, assisted by a most useful glossary of mining terms.

\section{SCIENCE AND ART AT THE ROYAL ACADEMY, 1945}

\author{
By DR. A. T. HOPWOOD \\ British Museum (Natural History)
}

$I^{1}$ $T$ is a commonplace of criticism that a painting is not only the result of the artist's competence and temperament, but also of his country and period. Thus a Titian could arise nowhere else than in Italy; neither could a Vermeer be found elsewhere than in the Low Countries. The former reflects the warm colouring of the south, and the patronage of opulent, semi-pagan princes and prelates, whereas the latter echoes the cooler skies of the north, and the solid worth of prosperous burgherdom. Some years ago, Frank Rutter, following an earlier suggestion by Sir Michael Sadler, pointed out that, from the commencement of the present century, art in the hands of its more advanced exponents became more and more violent until, in the last years before 1914 , men like Kandinsky and Wyndham Lewis were painting pictures of which the themes were connected in some way or another with war.

This prophetic aspect of the psychology of art can best be realized after study of pictures extending over some years, and it may be that the six war-time exhibitions of the Royal Academy do not constitute a long enough series; but one point in particular has attracted my attention, and to add emphasis I propose to illustrate it by reference to pictures painted by academicians, or associates, that is, to the work of men who, traditionally, are not included among the most advanced members of the craft.

Consider, first of all, Algernon Newton, who in 1942 exhibited bright and sunny scenes of London's canals. As the years have passed, his sunshine has gradually become less bright and more gloomy until in the present exhibition, even in pictures of the countryside (Nos. 348, 352, 363), it has achieved that blackish quality which gleams out fitfully before the storm, and in the town has become so dramatic as almost to be theatrical (No. 68). Sir Alfred Munnings is another whose sunshine is sometimes gloomy (No. 140) and whose skies are often sad (Nos. 136, 140). On the other hand, Edward Wadsworth has two longshore scenes (Nos. 711, 715) of a type sufficiently advanced to satisfy any but the most perfervid worshipper of 'isms'. His colours are strong and the first impression is one of stimulus akin to that of a cocktail, but the stimulus soon passes and a vague feoling of malaise, as it were a sense of the malevolence of the inanimate, remains. These might be thought a curious sequence and combination to occur as a long and hard-fought war drew slowly to a victorious close, but they are not unintelligible when considered in relation to the gradual realization of the thorny problems which would beset the peace. makers.

A painter's problems are exemplified by the work of James Fitton. "Woman Reading" (No. 61) and "Country Interior" (No.602) belong to a group of works which he has shown during the last few years, and which are chiefiy exercises in the management of red, perhaps the most difficult of all colours except purple, of which more later. These two canvases show, as they were bound to do, how the primary colour, red, tends towards its secondaries (orange and purple) and the secondaries towards the tertiaries; or, if this theory of colour be considered too old- 